\title{
PENGARUH SISTEM INFORMASI ADMINISTRASI KEUANGAN DAN ASET BERBASIS CLIENT SERVER TERHADAP PENINGKATAN KINERJA SANGGAR SENI TRI MELATI LAMONGAN
}

\author{
Octa Melinda Lucky Mahesta \\ Universitas Islam Lamongan \\ octamahesta7@gmail.com
}

\begin{abstract}
ABSTRAK
Sistem informasi sangat berperan penting dalam berkembangnya suatu organisasi, penerapan sistem informasi akan mempermudah pelaksanaan tugas yang dijalankan dan didukung oleh teknologi yang canggih sehingga dapat mempercepat penyelesaian tugas setiap individu. Setiap organisasi dituntut dapat selalu meningkatkan kualitas dan kuantitas kinerja untuk tercapainya tujuan yang ada. Dengan adanya sistem informasi yang baru saja dikembangkan, diharapkan akan meningkatkan kinerja pengurus dalam organisasi. Tujuan dari penelitian ini adalah untuk menganalisis dan menguji sistem informasi administrasi keuangan dan aset berbasis client server terhadap peningkatan kinerja pengurus Sanggar Seni Tri Melati Lamongan. Jenis penelitian yang digunakan dalam penelitian ini adalah penelitian kuantitatif dengan metode kausal komparatif menggunakan survey. Populasi dalam penelitian ini adalah seluruh pengurus Sanggar Seni Tri Melati Lamongan dan sampel yang digunakan berjumlah 42 orang. Data dikumpulkan dari kuesioner yang diberikan kepada 42 responden. Uji keandalan instrumen meliputi uji validitas dan uji reliabilitas. Sedangkan uji asumsi klasik meliputi uji normalitas dan uji heteroskedastisitas. Teknik analisis data menggunakan analisis regresi linier sederhana yang digunakan untuk menguji hipotesis. Berdasarkan hasil penelitian dapat disimpulkan bahwa penerapan sistem informasi administrasi keuangan dan aset berbasis client server berpengaruh signifikan terhadap peningkatan kinerja pengurus pada Sanggar Seni Tri Melati Lamongan. Hal ini terjadi karena meskipun pengembangan sistem informasi administrasi keuangan dan aset berbasis client server yang baru dilakukan dan diterapkan selama kurang lebih 1 bulan, namun dapat memberikan dampak positif kemudahan dan keunggulan bagi pengurus maupun anggota, sehingga terjadi peningkatan kinerja pengurus pada Sanggar Seni Tri Melati Lamongan. Pengaruh variabel pada penelitian ini masih kecil, oleh karena itu bagi penelitian selanjutnya dengan tema yang sama sebaiknya menambah jumlah variabel bebas, agar hasil penelitian menjadi lebih baik.
\end{abstract}

Kata kunci : Client Server, Kinerja, Regresi Linier Sederhana, Sistem Informasi

\section{PENDAHULUAN}

Ilmu pengetahuan dan teknologi pada masa sekarang berkembang semakin pesat. Hal ini dapat dilihat dari semakin banyaknya berbagai macam teknologi canggih yang dapat membantu aktivitas dalam kehidupan manusia, yang memungkinkan manusia untuk mendapatkan informasi secara cepat, tepat, dan akurat, sehingga dapat meningkatkan produktivitas. Dengan demikian teknologi informasi ber-peran sangat penting dalam setiap aspek seperti ilmu pengetahuan, pemerintah, ekonomi, 
dan teknologi. Teknologi informasi dapat berjalan dengan baik jika didukung oleh sumber daya manusia yang memadai, kombinasi dari keduannya akan membentuk sebuah sistem informasi yang bertujuan untuk mendukung operasi dan manajemen suatu organisasi. Pada penelitian Mahesta (2018) yaitu merancang dan mem-buat sistem informasi administrasi keuangan dan aset berbasis client server yang kemudian di aplikasikan dalam program aplikasi visual basic dan XAMPP selanjutnya diserahkan dan dikelola oleh Sanggar Seni Tri Melati Lamongan untuk mem-permudah pihak bagian keuangan dalam melakukan suatu pembayaran administrasi keuangan dan pendataan aset sehingga dapat meningkatkan efektifan dan efisiensi pada kinerja organisasi.

Penerapan sistem informasi administrasi keuangan dan aset berbasis client server yang telah dikembangkan oleh Mahesta (2018) untuk Sanggar Seni Tri Melati Lamongan baik secara langsung maupun tidak langsung akan mem-pengaruhi kinerja pengurus dalam organisasi tersebut. Setelah menggunakan sistem informasi berbasis client server diharapkan dapat mem-berikan suatu dampak yang positif terhadap kinerja pengurus Sanggar Seni Tri Melati Lamongan. Menurut Mangkunegara (2009:67) kinerja adalah hasil kerja secara kualitas dan kuantitas yang dicapai oleh seorang pegawai dalam melaksanakan tugas-nya sesuai dengan tanggung jawab yang diberikan kepadanya. Kinerja suatu organisasi dapat dilihat dari tingkatan sejauh mana organisasi tersebut dapat mencapai tujuan yang sudah direncanakan sebelumnya. Pencapaian peningkatan kinerja dapat dilihat dengan kesesuaian antara sistem informasi administrasi keuangan dan aset berbasis client server yang diterapkan pada Sanggar Seni Tri Melati Lamongan dengan tugas, kebutuhan, dan kemampuan yang dimiliki setiap pengurus dalam menyelesaikan suatu pekerjaan. Keberhasilan suatu sistem informasi dalam sebuah organisasi tergantung bagaimana sistem itu dijalankan, kemudahan sistem tersebut untuk penggunanya, dan hasil pemanfaatan teknologi sistem informasi yang di-gunakan. Penerapan sistem informasi yang baru dianggap berhasil atau sukses, apabila terjadi peningkatan kinerja pengurus dengan meng-hasilkan informasi yang berkualitas.

Berdasarkan latar belakang di atas, maka rumusan masalah penelitian adalah 
"Apakah setelah adanya sistem informasi administrasi keuangan dan aset berbasis client server berpengaruh terhadap pe-ningkatan kinerja pengurus Sanggar Seni Tri Melati Lamongan?”. Tujuan penelitian ini adalah untuk menganalisis dan menguji pengaruh suatu sistem informasi administrasi keuangan dan aset berbasis client server terhadap peningkatan kinerja pengurus Sanggar Seni Tri Melati Lamongan.

\section{METODE PENELITIAN}

Jenis penelitian yang di-gunakan oleh peneliti yaitu penelitian kuantitatif dengan metode kausal komparatif dengan meng-gunakan survey. Penelitian kausal komparatif adalah penelitian yang dilakukan untuk membandingkan suatu variabel (objek penelitian), antara subjek yang berbeda atau waktu yang berbeda dan menemukan hubungan sebabakibatnya (Emzir, 2010). Sedangkan metode survey merupakan suatu metode peng-umpulan data yang menggunakan kuesioner atau angket. Kuesioner merupakan teknik pengumpulan data yang dilakukan dengan cara memberi seperangkat pertanyaan atau per-nyataan tertulis kepada responden untuk kemudian dijawab (Sugiyono, 2012). Populasi dalam penelitian ini adalah seluruh pengurus dan anggota Sanggar
Seni Tri Melati Lamongan. Sedangkan sampel dalam penelitian ini adalah sebagian dari pengurus Sanggar yang berjumlah 42 orang yaitu, (1) pengurus 7 orang terdiri dari pimpinan, sekretaris 1 , sekretaris 2, bendahara 1, bendahara 2, humas, sumber daya manusia (SDM), dan (2) anggota 35 orang terdiri dari kelas anak 15 orang di wakili orang tua siswa, kelas remaja 10 orang, dan kelas tim 10 orang. Teknik peng-ambilan sampel yang digunakan adalah purposive sampling, teknik pengambilan sampel sumber data dengan pertimbangan tertentu (Sugiyono, 2013). Kriteria pengambilan sampel yaitu pengurus Sanggar yang telah menjabat selama kurang lebih dua periode atau 4 tahun, pengurus Sanggar yang ber-hubungan langsung dengan administrasi keuangan dan aset Sanggar.

Jenis data meliputi data primer dan data sekunder. Data primer dalam penelitian ini berupa kuesioner yang diberikan secara langsung kepada responden, ber-isikan tentang daftar pertanyaan berkaitan dengan Sistem Informasi Administrasi Keuangan dan Aset berbasis Client Server terhadap Peningkatan Kinerja pada Sanggar Seni Tri Melati Lamongan, untuk mengetahui tanggapan responden terkait dengan 
permasalahan dan tujuan penelitian. Data sekunder dalam penelitian ini didapat melalui skripsi, jurnal, buku, dan literatur lainnya berkaitan dengan penelitian ini. Metode pengumpulan data dalam penelitian ini adalah observasi, dokumentasi, dan kuesioner.

Variabel yang digunakan dalam penelitian ini adalah variabel bebas Sistem Informasi Administrasi Keuangan dan Aset berbasis Client Server, dan variabel terikat Pe-ningkatan Kinerja. Menurut Stair dan Reynolds (2012), sistem informasi adalah suatu sekumpulan elemen atau komponen berupa orang, prosedur, database, dan alat yang dapat dikumpulkan, disimpan, dan diolah untuk menyediakan output kepada user. Administrasi keuangan adalah proses pengelolaan yang melibatkan semua kegiatan yang berhubungan dengan keuangan, pem-buatan laporan keuangan, dan pen-capaian tujuan untuk kepentingan bersama (Wikipedia). Aset atau aktiva adalah sumber ekonomi yang diharapkan memberikan manfaat usaha di kemudian hari (Wikipedia). Menurut Mulyanto (2009), client server adalah arsitektur yang paling banyak dipakai di teknologi modern ini dimana client mampu melakukan proses secara mandiri saat meminta data dan server akan mengirimkan data sesuai permintaan kemudian proses akan dilakukan oleh client. Menurut Adi D (2001), peningkatan adalah kemajuan dari seseorang dari tidak tahu menjadi tahu, dari tidak bisa menjadi bisa. Peningkatan adalah proses, cara, perbuatan untuk menaikkan sesuatu atau usaha kegiatan untuk memajukan sesuatu ke suatu arah yang lebih baik lagi daripada sebelumnya. Menurut Mangkunegara (2009), kinerja adalah hasil kerja secara kualitas dan kuantitas yang dicapai oleh seorang pegawai dalam melaksanakan tugasnya sesuai dengan tanggung jawab yang diberikan kepadanya.

Adapun tahap-tahap analisis dalam penelitian ini meliputi, (1) Menganalisis Pengaruh Sistem Informasi Administrasi Keuangan dan Aset berbasis Client Server terhadap Peningkatan Kinerja Pengurus Sanggar Seni Tri Melati Lamongan menggunakan alat pengukuran data dari hasil survey melalui kuesioner dengan skala Likert. Menurut Sugiyono (2014) bahwa skala Likert digunakan untuk mengukur sikap, pendapat, dan persepsi seseorang atau sekelompok orang tentang fenomena sosial. Kriteria pemberian skor untuk alternatif jawaban untuk setiap item 
sebagai berikut, (1) Skor 1 untuk jawaban sangat tidak setuju, (2) Skor 2 untuk jawaban tidak setuju, (3) Skor 3 untuk jawaban ragu-ragu, (4) Skor 4 untuk jawaban setuju, (5) Skor 5 untuk jawaban sangat setuju. (2) Data kuesioner variabel bebas dan variabel terikat diolah meng-gunakan analisis regresi linier sederhana dalam aplikasi program SPSS.

\section{HASIL PENELITIAN DAN PEMBAHASAN}

\subsection{Gambaran Umum Responden}

Dalam melakukan penelitian ini, peneliti menyebar kuesioner kepada pengurus dan anggota Sanggar Seni Tri Melati Lamongan. Kuesioner ini terdiri dari dua bagian, yang pertama adalah tanggapan responden terhadap sistem informasi administrasi keuangan dan aset berbasis client server dan yang kedua adalah tanggapan responden mengenai peningkatan kinerja pengurus Sanggar.

Berikut adalah gambaran mengenai pengurus dan anggota yang menjadi responden dalam penelitian ini, yang dikelompokkan berdasarkan jenis kelamin, dan umur.
Tabel 1. Karakteristik Responden Berdasarkan Jenis Kelamin

\begin{tabular}{|c|c|c|}
\hline $\begin{array}{c}\text { Jenis } \\
\text { Kelamin }\end{array}$ & $\begin{array}{c}\text { Jumlah } \\
\text { Responden }\end{array}$ & $\begin{array}{c}\text { Persentase } \\
(\%)\end{array}$ \\
\hline Laki-laki & 6 & $14,29 \%$ \\
\hline Perempuan & 36 & $85,71 \%$ \\
\hline Jumlah & 42 & $100 \%$ \\
\hline \multicolumn{2}{|c|}{ Sumber : Data Olahan }
\end{tabular}

Tabel 1 menggambarkan bahwa dari 42 orang yang menjadi objek penelitian, 6 orang adalah berjenis kelamin laki-laki $(14,29 \%)$ dan 36 orang adalah berjenis kelamin perempuan $(85,71 \%)$.

Tabel 2. Karakteristik Responden Berdasarkan Umur

\begin{tabular}{|c|c|c|}
\hline Umur & $\begin{array}{c}\text { Jumlah } \\
\text { Responden }\end{array}$ & $\begin{array}{c}\text { Persentase } \\
(\boldsymbol{\%})\end{array}$ \\
\hline $13-17$ thn & 11 & $26,19 \%$ \\
\hline $18-22$ thn & 9 & $21,43 \%$ \\
\hline $26-30$ thn & 18 & $42,86 \%$ \\
\hline $31-35$ thn & 2 & $4,76 \%$ \\
\hline $36-40$ thn & 2 & $4,76 \%$ \\
\hline Jumlah & 42 & $100 \%$ \\
\hline
\end{tabular}

Dari Tabel 2 menunjukkan bahwa pengurus dan anggota Sanggar Seni Tri Melati yang berumur 13-17 tahun sebanyak 11 orang $(26,19 \%), 18-22$ tahun sebanyak 9 orang (21,435), 26-30 tahun sebanyak 18 orang $(42,86 \%)$, yang berusia 31-35 tahun sebanyak 2 orang $(4,76 \%)$, dan yang berusia $36-40$ tahun sebanyak 2 orang $(4,76 \%)$.

\subsection{Deskripsi Variabel Penelitian}

Berdasarkan dari hasil jawaban kuesioner yang telah disebar kemudian diisi oleh pengurus dan anggota Sanggar mengenai Sistem Informasi Administrasi 
Keuangan dan Aset berbasis Client Server diperoleh hasil sebagai berikut :

Tabel 3. Hasil Tanggapan Responden Terhadap Sistem Informasi Administrasi Keuangan dan Aset berbasis Client Server

\begin{tabular}{|c|l|c|}
\hline No & \multicolumn{1}{|c|}{ Pernyataan } & Mean \\
\hline 1 & $\begin{array}{l}\text { Sistem informasi } \\
\text { menyediakan data yang } \\
\text { akurat }\end{array}$ & 4,21 \\
\hline 2 & $\begin{array}{l}\text { Sistem informasi } \\
\text { menyediakan data yang } \\
\text { terbaru (uptodate) }\end{array}$ & 4,21 \\
\hline 3 & $\begin{array}{l}\text { Sistem informasi memiliki } \\
\text { menu dan fungsi yang } \\
\text { penting (format ringkas, } \\
\text { jelas \& mudah dipahami) }\end{array}$ & 4,21 \\
\hline 4 & $\begin{array}{l}\text { Sistem informasi sesuai } \\
\text { dengan kebutuhan pengguna }\end{array}$ & 4,26 \\
\hline 5 & $\begin{array}{l}\text { Sistem informasi berjalan } \\
\text { secara akurat dan berfungsi } \\
\text { sebagaimana mestinya. }\end{array}$ & 4,17 \\
\hline $\begin{array}{l}\text { Mean Secara Keseluruhan Variabel } \\
\text { Sistem Informasi Administrasi } \\
\text { Keuangan dan Aset berbasis Client } \\
\text { Server (X) }\end{array}$ & 4,21 \\
\hline \multicolumn{3}{|c|}{ Sumber : Data Olahan } \\
\hline
\end{tabular}

Berdasarkan pada Tabel 3 dapat disimpulkan bahwa variabel Sistem Informasi Administrasi Keuangan dan Aset berbasis Client Server (X) sebagian besar pengurus dan anggota menyatakan setuju pada pernyataan "Sistem informasi sesuai dengan kebutuhan pengguna“, dengan memiliki nilai ratarata 4,26 . Hal ini menunjukkan bahwa pengurus dan anggota menganggap setelah menggunakan Sistem Informasi berbasis Client Server dalam mendukung aktivitas pekerjaan yang ada di Sanggar selama ini telah dilakukan dengan baik oleh pengurus.

Tabel 4. Hasil Tanggapan Responden Terhadap Peningkatan Kinerja

\begin{tabular}{|l|l|c|}
\hline No & \multicolumn{1}{|c|}{ Pernyataan } & Mean \\
\hline 1 & $\begin{array}{l}\text { Admin sistem informasi selalu } \\
\text { memberikan pelayanan saat } \\
\text { dibutuhkan }\end{array}$ & 4,26 \\
\hline 3 & $\begin{array}{l}\text { Admin sistem informasi } \\
\text { memberikan respon yang } \\
\text { cepat terhadap kebutuhan } \\
\text { anggota Sanggar }\end{array}$ & 4,36 \\
\hline 4 & $\begin{array}{l}\text { Admin sistem informasi } \\
\text { memiliki pengetahuan dan } \\
\text { keahlian dalam mengerjakan } \\
\text { tugasnya }\end{array}$ & 4,07 \\
\hline $\begin{array}{l}\text { Admin sistem informasi } \\
\text { memberikan pelayanan yang } \\
\text { cepat dan akurat }\end{array}$ & 4,07 \\
\hline 5 & $\begin{array}{l}\text { Pekerjaan admin sistem } \\
\text { informasi menjadi lebih } \\
\text { efektif dan efisien }\end{array}$ & 4,36 \\
\hline $\begin{array}{l}\text { Mean Secara Keseluruhan Variabel } \\
\text { Peningkatan Kinerja }\end{array}$ & 4,22 \\
\hline \multicolumn{3}{|c|}{ Sumber : Data Olahan } \\
Berdasarkan pada Tabel
\end{tabular}

disimpulkan bahwa variabel Peningkatan Kinerja (Y) sebagian besar pengurus dan anggota menyatakan setuju pada pernyataan "Admin sistem informasi mem-berikan respon yang cepat terhadap kebutuhan anggota Sanggar", dan pernyataan "Pekerjaan admin sistem informasi menjadi lebih efektif dan efisien", dengan memiliki nilai rata-rata 4,36 .

Berdasarkan tanggapan atas pernyataan peningkatan kinerja tersebut tidak terdapat permasalahan, karena mayoritas menjawab setuju. Dengan adanya penilaian pe-ningkatan kinerja 
akan memotivasi pengurus untuk bekerja sebaik mungkin dalam mencapai tujuan yang telah ditetapkan oleh Sanggar, dan anggota menjadi lebih nyaman karena pelayanan yang memuaskan. Penilaian peningkatan kinerja me-rupakan kegiatan memastikan bahwa tujuantujuan Sanggar telah tercapai secara kuantitas maupun kualitas, yang telah dilakukan dengan baik oleh Sanggar Seni Tri Melati Lamongan.

\subsection{Uji Validitas}

Hasil uji validitas dengan menggunakan bantuan program SPSS dapat disajikan dalam Tabel 5 berikut ini.

Tabel 5. Hasil Uji Validitas

\begin{tabular}{|c|c|c|c|c|}
\hline Variabel & Pernyataan & r hitung & r tabel & Ket. \\
\hline \multirow{5}{*}{$\begin{array}{l}\text { Sistem } \\
\text { Informasi } \\
\text { Administrasi } \\
\text { Keuangan } \\
\text { dan Aset } \\
\text { Berbasis } \\
\text { Client } \\
\text { Server (X) }\end{array}$} & $\mathrm{X} 1$ & 0,727 & 0,3 & Valid \\
\hline & $\mathrm{X} 2$ & 0,727 & 0,3 & Valid \\
\hline & X3 & 0,699 & 0,3 & Valid \\
\hline & $\mathrm{X} 4$ & 0,724 & 0,3 & Valid \\
\hline & $\mathrm{X5}$ & 0,804 & 0,3 & Valid \\
\hline
\end{tabular}

\begin{tabular}{|c|c|c|c|c|}
\hline Variabel & Pernyataan & r hitung & r tabel & Ket. \\
\hline $\begin{array}{c}\text { Peningkatan } \\
\text { Kinerja (Y) }\end{array}$ & Y1 & 0,798 & 0,3 & Valid \\
\cline { 2 - 5 } & Y2 & 0,644 & 0,3 & Valid \\
\cline { 2 - 5 } & Y3 & 0,822 & 0,3 & Valid \\
\cline { 2 - 5 } & Y4 & 0,746 & 0,3 & Valid \\
\cline { 2 - 5 } & Y5 & 0,637 & 0,3 & Valid \\
\hline
\end{tabular}

Berdasarkan tabel hasil uji validitas untuk setiap pernyataan di atas dapat dilihat bahwa nilai $r$ hitung untuk masing-masing per-nyataan variabel

\subsection{Uji Reliabilitas}

Berdasarkan Tabel 5 di atas telah dilakukan uji validitas, maka langkah selanjutnya peneliti me-lakukan uji reliabilitas terhadap data kuesioner agar data kuesioner reliabel. Berikut hasil uji reliabilitas yang disajikan pada Tabel 6 berada di atas 0,3. Hal ini menunjukkan bahwa data tersebut valid dan layak untuk diuji.

Tabel 6. Hasil Uji Reliabilitas

\begin{tabular}{|l|c|c|c|}
\hline \multicolumn{1}{|c|}{ Variabel } & $\begin{array}{c}\text { Cronbach } \\
\text { 's Alpha }\end{array}$ & $\begin{array}{c}\text { Kriteria } \\
\text { Uji }\end{array}$ & Ket. \\
\hline $\begin{array}{l}\text { Sistem } \\
\text { Informasi } \\
\text { Administrasi } \\
\text { Keuangan } \\
\text { dan Aset } \\
\text { Berbasis } \\
\text { Client Server } \\
\text { (X) }\end{array}$ & 0,789 & 0,6 & Reliabel \\
\hline $\begin{array}{l}\text { Peningkatan } \\
\text { Kinerja (Y) }\end{array}$ & 0,783 & 0,6 & Reliabel \\
\hline \multicolumn{2}{|c|}{ Sumber : Hasil Output SPSS } \\
\hline
\end{tabular}


Berdasarkan dari tabel di atas menunjukkan bahwa variabel independent maupun dependent dapat dikatakan reliabel, karena nilai Cronbach's Alpha > kiteria uji 0,6. Dengan demikian dapat disimpulkan bahwa data kuesioner yang digunakan dalam penelitian ini sudah representatif, dalam artian pengukuran datanya dapat dipercaya.

\subsection{Uji Normalitas}

Melalui aplikasi program SPSS maka dapat disajikan hasil uji normalitas dibawah ini :

Tabel 7. Hasil Uji Normalitas

\begin{tabular}{|c|c|c|}
\hline & & $\begin{array}{r}\text { Unstandardized } \\
\text { Residual }\end{array}$ \\
\hline $\mathrm{N}$ & & 42 \\
\hline \multirow{3}{*}{$\begin{array}{l}\text { Normal } \\
\text { Parameters }\end{array}$} & Mean & 0,0000000 \\
\hline & & \\
\hline & $\begin{array}{l}\text { Standard } \\
\text { Deviation }\end{array}$ & 2,51976179 \\
\hline \multirow{4}{*}{$\begin{array}{l}\text { Most Extreme } \\
\text { Differences }\end{array}$} & Absolute & 0,095 \\
\hline & & \\
\hline & Positive & 0,095 \\
\hline & Negative & $-0,062$ \\
\hline $\begin{array}{l}\text { Kolmogorov- } \\
\text { Smirnov Z }\end{array}$ & & 0,095 \\
\hline $\begin{array}{l}\text { Asymp. Sig. (2- } \\
\text { tailed) }\end{array}$ & & 0,200 \\
\hline
\end{tabular}

Berdasarkan pada Tabel 7 dapat diketahui bahwa besarnya nilai Asymp. Sig. (2-tailed) sebesar 0,200 >0,05. Hal ini sesuai dengan ketentuan yang telah ditetapkan, maka dapat disimpulkan bahwa data tersebut berdistribusi normal dan dapat digunakan dalam penelitian.

\subsection{Uji Heteroskedastisitas}

Uji heteroskedastisitas pada dasarnya bertujuan untuk menguji apakah dalam model regresi terjadi ketidaksamaan varians dari residual satu pengamatan ke pengamatan yang lain. Dasar pengambilan ke-putusan pada uji heteroskedastisitas yakni :

1. Jika nilai signifikansi lebih besar dari 0,05 kesimpulannya adalah tidak terjadi heteroskedastisitas.

2. Jika nilai signifikansi lebih kecil dari 0,05 kesimpulannya adalah terjadi heteroskedastisitas.

Tabel 8. Hasil Uji Heteroskedastisitas

\begin{tabular}{|c|c|c|}
\hline Variabel & Sig $t$ & Keterangan \\
\hline $\begin{array}{l}\text { Sistem } \\
\text { Informasi } \\
\text { Administrasi } \\
\text { Keuangan } \\
\text { dan Aset } \\
\text { Berbasis } \\
\text { Client Server }\end{array}$ & 0,118 & $\begin{array}{l}\text { Tidak terjadi } \\
\text { heteroskedastisitas }\end{array}$ \\
\hline
\end{tabular}

menunjukkan bahwa variabel independent memiliki nilai probabilitas signifikansi yang lebih besar dari 0,05, yaitu sebesar 0,118. Sehingga dapat disimpulkan bahwa tidak terjadi heteroskedastisitas dalam model regresi tersebut.

\subsection{Analisis Regresi Linier Sederhana}

Berikut adalah perhitungan analisis regresi linier sederhana menggunakan 
aplikasi program SPSS yang tersaji pada Tabel 9

Tabel 9. Hasil Regresi

\begin{tabular}{|c|c|c|c|c|c|c|}
\hline \multirow{2}{*}{\multicolumn{2}{|c|}{ Model }} & \multicolumn{2}{|c|}{$\begin{array}{c}\text { Unstandar- } \\
\text { dized Coefficients }\end{array}$} & \multirow{3}{*}{ 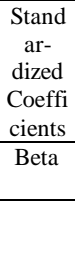 } & \multirow{3}{*}{$\begin{array}{c}\mathrm{T} \\
3,653\end{array}$} & \multirow{3}{*}{$\begin{array}{c}\text { Sig. } \\
0,001\end{array}$} \\
\hline & & \multirow{2}{*}{$\begin{array}{l}\text { B } \\
11,024\end{array}$} & \multirow{2}{*}{$\begin{array}{c}\text { Std } \\
\text {.Error } \\
3,018\end{array}$} & & & \\
\hline & $\begin{array}{l}\text { (Consta } \\
\mathrm{nt})\end{array}$ & & & & & \\
\hline 1 & $\begin{array}{l}\text { Sistem } \\
\text { Inform } \\
\text { asi } \\
\text { Admini } \\
\text { strasi } \\
\text { Keuang } \\
\text { an dan } \\
\text { Aset } \\
\text { Berbasi } \\
\text { s Client } \\
\text { Server }\end{array}$ & 0,479 & 0,142 & 0,471 & 3,374 & 0,002 \\
\hline
\end{tabular}

Dengan demikian diperoleh persamaan regresi linier sederhana sebagai berikut :

$$
\mathrm{Y}=\alpha+\mathrm{bX}+\mathrm{e}
$$

Dari persamaan regresi linier sederhana di atas diperoleh persamaannya yaitu, $\mathrm{Y}=11,024+$ $0,479 \mathrm{X}+$ e. Sehingga, peningkatan kinerja $=11,024+0,479$ sistem informasi administrasi keuangan dan aset berbasis client server $+\mathrm{e}$, nilai konstanta $(\alpha)$ sebesar 11,024. Artinya adalah apabila sistem informasi administrasi keuangan dan aset berbasis client server diasumsikan nol (0), maka peningkatan kinerja bernilai 11,024. Nilai koefisien regresi variabel sistem informasi administrasi keuangan dan aset berbasis client server sebesar 0,479. Artinya adalah apabila sistem informasi administrasi keuangan dan aset berbasis client server meningkat sebesar 1 satuan maka akan terjadi peningkatan kinerja pengurus sebesar 0,479 .

Untuk mengetahui besarnya pengaruh sistem informasi administrasi keuangan dan aset berbasis client server terhadap pe-ningkatan kinerja dalam penelitian ini dilihat dari besarnya koefisien determinasi $\left(\mathrm{R}^{2}\right)$ sebagaimana yang tersaji pada Tabel 10

Tabel 10. Koefisien Determinasi $\left(\mathrm{R}^{2}\right)$

\begin{tabular}{|c|c|c|c|c|}
\hline \multicolumn{5}{|c|}{ Model Summary } \\
\hline $\begin{array}{c}\text { Mode } \\
1\end{array}$ & $\mathrm{R}$ & $\begin{array}{c}\mathrm{R} \\
\text { Square }\end{array}$ & $\begin{array}{l}\text { Adjusted } \\
\text { R Square }\end{array}$ & $\begin{array}{c}\text { Std. } \\
\text { Error of } \\
\text { the } \\
\text { Estimate }\end{array}$ \\
\hline 1 & 0,471 & 0.222 & 0,202 & 2,55106 \\
\hline
\end{tabular}

Analisis data yang telah dilakukan menghasilkan nilai $\mathrm{R}$ sebesar 0,471 berarti hubungan ke-eratan secara bersama-sama antara variabel dependent dan variabel independent dinilai lemah, karena $\mathrm{R}<0,5$. Nilai $\mathrm{R}$ Square sebesar 0,222 artinya $22 \%$ sistem informasi administrasi keuangan dan aset berbasis client server kurang mempengaruhi peningkatan kinerja pengurus Sanggar Seni Tri Melati Lamongan, sedangkan sisanya yaitu $78 \% \quad(100 \%-22 \%)$ dipengaruhi oleh variabel lain yang tidak diteliti pada penelitian ini. 


\subsection{Uji Koefisien Regresi Secara Parsial (Uji t)}

Untuk mengetahui apakah pengaruh tersebut signifikan atau tidak, maka nilai koefisien regresi dari variabel sistem informasi administrasi keuangan dan aset berbasis client server (X) akan diuji signifikansinya. Hipotesis (dugaan) dalam uji t ini adalah sebagai berikut:

1. Ho $=$ sistem informasi administrasi keuangan dan aset berbasis client server (X) tidak berpengaruh signifikan terhadap peningkatan kinerja (Y).

2. $\mathrm{Ha}=$ sistem informasi administrasi keuangan dan aset berbasis client server $(\mathrm{X})$ berpengaruh signifikan terhadap peningkatan kinerja (Y).

Dasar pengambilan keputusan dalam uji t ini adalah sebagai berikut:

1. Ho diterima dan Ha ditolak, jika nilai $\mathrm{t}$ hitung $<\mathrm{t}$ tabel atau jika nilai Sig. $>$ 0,05 .

2. Ho ditolak dan Ha diterima, jika nilai $\mathrm{t}$ hitung $>\mathrm{t}$ tabel atau jika nilai Sig. < 0,05 .

Diketahui nilai $t$ tabel pada taraf signifikansi 5\% yaitu sebesar 2,021

Dari Tabel 9 hasil regresi di atas dapat dilihat bahwa variabel sistem informasi administrasi ke-uangan dan aset berbasis client server nilai t hitung
3,374 > t tabel 2,021 dan Sig. 0,02 < 0,05. Maka dapat disimpulkan bahwa Ho ditolak dan Ha diterima, yang artinya sistem informasi administrasi keuangan dan aset berbasis client server (X) berpengaruh signifikan terhadap peningkatan kinerja (Y).

\section{9 Uji Hipotesis}

Berdasarkan hasil perhitungan menggunakan aplikasi program SPSS dihasilkan uji t sebagaimana yang tersaji pada Tabel 11

Tabel 11. Hasil Pengujian Hipotesis

\begin{tabular}{|l|c|c|c|}
\hline \multicolumn{1}{|c|}{ Variabel } & t-hitung & Sig. & Keterangan \\
\hline Sistem & & & \\
Informasi \\
$\begin{array}{l}\text { Administrasi } \\
\text { Keuangan } \\
\text { dan Aset }\end{array}$ & 3,374 & 0,002 & $\begin{array}{c}\text { Berpengaruh } \\
\text { Signifikan } \\
\text { Berbasis } \\
\begin{array}{l}\text { Client } \\
\text { Server }\end{array}\end{array}$ \\
\multicolumn{2}{|l|}{ Sumber : Hasil Ouput SPSS } & & \\
\hline
\end{tabular}

Berdasarkan nilai $\mathrm{t}$ hitung sebesar 3,374 dengan signifikansi sebesar 0,002 $<0,05$, artinya nilai $\mathrm{t}$ hitung $>\mathrm{t}$ tabel atau nilai Sig. $<0,05$. Sehingga terbukti bahwa Ho ditolak dan Ha diterima, yang artinya secara parsial sistem informasi administrasi keuangan dan aset berbasis client server $(\mathrm{X})$ berpengaruh signifikan terhadap peningkatan kinerja (Y) pada Sanggar Seni Tri Melati Lamongan. 


\section{PENUTUP}

\subsection{Kesimpulan}

Berdasarkan hasil penelitian pada bab sebelumnya, maka peneliti dapat membuat beberapa kesimpulan sebagai berikut :

1. Berdasarkan hasil uji $\mathrm{t}$ dalam hipotesis dimana angka Sig. 0,002 < 0,05 . Dengan demikian terdapat pengaruh yang sig-nifikan atas sistem informasi administrasi keuangan dan aset berbasis client server terhadap peningkatan kinerja pengurus pada Sanggar Seni Tri Melati Lamongan. Hal ini menunjukkan meskipun adanya suatu pengembangan sistem informasi administrasi ke-uangan dan aset berbasis client server yang baru dilakukan dan diterapkan selama kurang lebih 1 bulan, namun terbukti mem-berikan kemudahan dan ke-unggulan bagi pengurus mau-pun anggota, sehingga terjadi peningkatan kinerja pengurus pada Sanggar Seni Tri Melati Lamongan.

2. $\mathrm{R}$ Square $\left(\mathrm{R}^{2}\right)$ dari hasil penelitian ini menunjukkan angka sebesar 0,222 . Hal ini berarti bahwa sistem informasi administrasi keuangan dan aset berbasis client server hanya mampu menjelaskan kinerja pengurus sebesar 22\%. Sedangkan $78 \%$ dipengaruhi variabel yang tidak ada pada penelitian ini.

3. Dari persamaan regresi linier sederhana dalam penelitian ini telah diperoleh persamaan $\mathrm{Y}=11,024+$ 0,479X. Persamaan ini menunjukkan bahwa setiap perubahan pada variabel X (sistem informasi administrasi keuangan dan aset berbasis client server) sebesar 1 nilai akan menyebabkan perubahan pada variabel $\mathrm{Y}$ (peningkatan kinerja) sebesar 0,479.

\subsection{Saran}

Berdasarkan kesimpulan di atas, sehingga saran-saran yang dapat peneliti berikan sebagai berikut :

1. Hasil koefisien determinasi sebesar 0,222 menunjukkan variabel bebas mempengaruhi variabel terikatnya hanya $22 \%$. Sehingga pengaruh variabel bebas tersebut masih kecil, oleh karena itu bagi peneliti yang akan meneliti dengan tema yang sama sebaiknya menambah jumlah variabel bebas, agar hasil penelitian menjadi lebih baik.

\section{DAFTAR PUSTAKA}

D, Adi. 2001. Kamus Praktis Bahasa Indonesia. Fajar Mulya, Surabaya Emzir. 2010. Metodologi Penelitian Pendidikan : Kuantitatif dan 
Kualitatif. Salemba Empat, Jakarta

Mahesta, Octa M. L. 2018. Perancangan Sistem Informasi Administrasi Keuangan dan Aset Meningkatkan Kinerja Pada Sanggar Seni Tri Melati Lamongan Berbasis Client Server. Skripsi. Lamongan : Program Sarjana Ekonomi Akuntansi Universitas Islam Lamongan.

Mangkunegara, A.A Anwar Prabu. 2009. Manajemen Sumber Daya Manusia. PT Remaja Rosdakarya, Bandung

Mulyanto, Agus. 2009. Sistem Informasi Konsep dan Aplikasi. Pustaka Pelajar, Yogyakarta

Rizaldi, Fahmi. 2015. Pengaruh Sistem Informasi Akuntansi terhadap Kinerja Karyawan: Studi Empiris pada CV Teguh Karya Utama Surabaya. Jurnal Ilmu dan Riset Akuntansi. Volume 4; Nomor 10.

Santosa, Dhika Anggara. 2013. Pengaruh Pemanfaatan Teknologi Informasi Terhadap Kinerja Individu Mahasiswa Program Pendidikan Strata Satu Jurusan Akuntansi Di STIE Perbanas Surabaya. Artikel Ilmiah. Surabaya : STIE Surabaya.

Stair, Raplh M., dan Reynolds, George W. 2012. Fundamental of Information Systems (with Access Code). Cengage, USA

Sugiyono. 2012. Metode Penelitian Kuantitatif, Kualitatif dan $R \& D$. Alfabeta, Bandung
Sugiyono. 2013. Metode Penelitian Kuantitatif, Kualitatif dan $R \& D$. Alfabeta, Bandung

Sugiyono. 2014. Metode Penelitian Pendidikan Pendekatan Kuantitatif, Kualitatif dan $R \& D$. Alfabeta, Bandung

Wikipedia. Pengertian Aset. (Online). (https://id.m.wikipedia.org/wiki/ Aset), (diakses 31 Maret 2018)

Wikipedia. Pengertian Administrasi Keuangan. (Online). (https://leninurmayanti04.wordpr ess.com/2014/03/31/pengertiankeuangan-dan-administrasikeuangan/), (diakses 31 Maret 2018)

Wiseliner, Ririn. 2013. Pengaruh Penerapan Teknologi Informasi Terhadap Kinerja Karyawan Pada PT. Serasi Autoraya-Trac Astra Rent a Car Cabang Pekanbaru. Skripsi. Pekanbaru: Program Sarjana Ekonomi dan Ilmu Sosial Universitas Islam Negeri Sultan Syarif Kasim Riau. 